\title{
Effectiveness of silicon and silicate salts for controlling black root rot and induced pathogenesis-related protein of strawberry plants
}

Farid Abd-El-Kareem, Ibrahim E. Elshahawy and Mahfouz M. M. Abd-Elgawad (D)

\begin{abstract}
Background: Black root rot is a complex disease caused by one or more of fungal pathogens especially Rhizoctonia solani and Fusarium solani. It is a serious, yield-limiting disease of strawberry plants. A considerable incidence of black root rot has been observed in recent years in Egypt.

Materials/methods: Evaluation of silicon as well as potassium, sodium, and calcium silicates against black root rot and induced pathogenesis-related (PR) protein under field conditions was investigated herein. Four concentrations, i.e., $0,2,4$, and $6 \mathrm{~g} / \mathrm{l}$ of silicon, potassium, sodium, and calcium silicates, were tested to study their effect on growth of strawberry black root fungi (F. solani and R. solani) under laboratory and field conditions.

Results: Complete inhibition of fungal linear growth was observed with 4 and $6 \mathrm{~g} / \mathrm{l}$ for $R$. solani and F. solani, respectively, in the laboratory. Under field conditions, all tested concentrations significantly reduced the disease incidence and severity. The highest reduction of such disease incidence and severity was obtained with potassium silicate and calcium silicate applied separately as soil treatment combined with foliar sprays which reduced the disease incidence and severity by 92.7 and 91.9 , and 91.7 and 91.1\%, respectively. The highest yield increase, i.e., 77.1 and $72.8 \%$, was obtained with potassium silicate and calcium silicate, respectively, applied as soil treatment + foliar spray. Results indicated that 8 to 12 new protein patterns (bands) appeared in the tested treatments.

Conclusions: No-standalone management measure is perfectly effective against the black root-rot complex. Thus, an integrated management including tactful cultural practices and applying foliar and soil inputs, e.g., silicon salts reported herein, can effectively control the disease and enhance strawberry yield.
\end{abstract}

Keywords: Black root rot, Protein patterns, Silicon, Silicate salts, Strawberry

\section{Background}

The current increase in strawberry (Fragaria $\times$ ananassa Duchesne) acreage in Egypt is frequently associated with high infestation with soilborne fungi. The lack of their control can result in a significant reduction in strawberry yield and fruit quality. Black root rot, a complex disease caused by one or more of fungal pathogens, e.g., Fusarium oxysporum (Juber et al. 2014), Macrophomina phaseolina (Hutton et al. 2013), and Rhizoctonia spp. (Fang et al. 2013), ranks high among other diseases. A

\footnotetext{
* Correspondence: mahfouzian2000@yahoo.com

Plant Pathology Department, National Research Centre, Dokki, Giza 12622, Egypt
}

considerable incidence of this root rot disease has been observed in recent years in Egypt. Our field observations indicated that it is frequently caused by Rhizoctonia solani and Fusarium solani in Egypt. The disease is characterized by feeder rootlet killing, deterioration, and blackening of the main root system and a decline in vigor and productivity of the plant stand causing damage to the host and considerable reduction in the yield (Botha et al. 2001; Fang et al. 2013; Ceja-Torres et al. 2014).

Silicon ( $\mathrm{Si}$ ) has been reported to play a vital role to effectively mitigate various environmental stresses and enhance plant resistance against both fungal and bacterial pathogens (Forbes and Watson 1992; Wang et al. 2017). 
Its amount within plant tissues of different species considerably varies due to differences related to root uptake capacity. Generally, Si uptake occurs via plant roots as silicic acid $\left[\mathrm{Si}(\mathrm{OH})_{4}\right]$, an uncharged molecule, and passes through the plasma membrane by two Si transporters, Lsil and Lsi2, which function as influx transporters and efflux transporters, respectively (Wang et al. 2017). Silicon has an important potential in the plant growth and development (Datnoff et al. 2001). Potassium silicate is the main source of soluble potassium and silicon. In general, plants require silica to resist against biotic and abiotic stress (Ma 2004). Soil amendment by such a solution resulted in enhancing plant growth, yield, and disease and insect resistance and reduced the harmful mineral toxicities (Bélanger et al. 1995). So, fungal diseases such as powdery mildew and root rot were suppressed while the amount of chemical fungicides released into the environment was decreased by application of silicic acid (Bélanger et al. 1995; Ma 2004).

Thus, the development of safe alternatives to environmentally unfriendly fungicides would be useful to avoid environmental pollution and health hazards (Kumar 2007; Khalifa et al. 2013). Since Si play a vital role in leaf development, consequently exposing more leaves to light, it can increase the efficiency of plant canopy photosynthesis. On the other hand, plants exposed to different environmental stresses including disease infections exhibit changes in membrane leakage that lead to loss of membrane integrity (Blokhina et al. 2003).

The aim of this study was to evaluate the effect of silicon, as well as potassium, sodium, and calcium silicates, against strawberry black root rot under laboratory and field conditions in Egypt. The effect of these treatments on protein patterns of strawberry plants was examined.

\section{Materials and methods}

\section{Pathogens and plant material}

Pathogenic isolates of F. solani and R. solani, the causal agents of black root disease of strawberry plants, were kindly provided by Plant Pathology Department, National Research Centre, Giza, Egypt. Strawberry seedlings (cv. Festival) were obtained from Vegetable Crops Research Dept., Agricultural Research Centre, Giza, Egypt. At the end of November 2017, strawberry seedlings were transplanted into a field with loamy clay, well-drained soil, and final harvest was at the end of April, 2018.

\section{Laboratory testing}

Three concentrations, i.e., 2, 4, and 6 ( $\mathrm{ml} / \mathrm{l})$ of silicon, potassium, sodium, and calcium silicates, in addition to the untreated control (only water), were tested to study their effect on linear growth of strawberry black root rot fungi ( $F$. solani and $R$. solani) in the laboratory. These concentrations were added individually to sterilized potato dextrose agar (PDA) before solidification and then poured in sterile 9-cm-diameter Petri-plates. After solidification, the plates were inoculated with 6-mm fungal disc in the center of the plate and incubated at $25 \pm 1{ }^{\circ} \mathrm{C}$. Five plates per concentration for each fungus were used as replicates; five plates served as control/ fungus. Linear growth was recorded, and reduction in linear growth was estimated.

\section{Field testing}

A field experiment was carried out at Tukh district, ElQalioubia governorate, Egypt. Chosen field was naturally highly infested with strawberry black root rot fungi from previous season. The experiment was conducted under natural infection by both $F$. solani and $R$. solani in plots $(4 \times 8 \mathrm{~m})$, each comprised of 8 rows (32 holes/ row and a seedling was sown in each hole) in a randomized complete block design with three replicates (plots) for each treatment. Strawberry seedlings were planted in loamy clay well-drained soil to a depth of $10 \mathrm{~cm}$. In addition, irrigation, fertilization, and other nutrients were added as recommended (El-Shemy et al. 2013). Silicon, potassium, sodium and calcium silicates were tested at concentration of $6 \mathrm{~g} / \mathrm{l}$ to study their effect on strawberry black rot, plant weight, and yield under field conditions.

\section{Application}

Silicon, potassium, sodium, and calcium silicates, each at concentration of $6 \mathrm{~g} / \mathrm{l}$, were applied as soil treatments as well as soil + foliar spray every 15 days for 4 months. Soil in intimate contact with strawberry roots received $40 \mathrm{ml}$ of each treatment but soil and plant received $80 \mathrm{ml}$ of each treatment for soil + foliar spray as fifty-fifty.

\section{Assessment of disease incidence}

The percentage of disease incidence was calculated 100 days after transplanting as follows:

$$
\text { Disease incidence } \%=\frac{\text { Number of infected plants }}{\text { Total number of plants }} \times 100
$$

Disease severity (DS) was recorded at the end of the experiment, 5 months after transplanting, according to the following scale (Morocko 2006): 0: plant well developed, no disease symptoms; 1: no visible symptoms on plant foliage, $25 \%$ of roots discolored; 2: plant slightly stunted, black necrosis on petiole bases, $26-50 \%$ of roots discolored; 3: plant stunted, black necrosis on petiole bases, yellowing and death of outer leaves, $51-75 \%$ of roots discolored; 4: plant severely stunted, outer leaves collapsed, younger leaves bluish green and wilting, $>75 \%$ of roots discolored; and 5: roots almost completely discolored and plant almost dead. 
Disease severity $\%=\frac{\sum(\text { Disease grade } \times \text { Number of plants in each grade })}{\text { Total number of plants } \times \text { Highest disease grade }} \times 100$

\section{Effect on plant weight and yield of strawberry plants under field conditions}

Fresh and dray weights per plant were determined at harvest. Accumulated strawberry fruit yield (Ton/feddan) for each treatment was determined.

\section{Protein pattern analysis}

\section{Isolation of total plant proteins}

Sixty days after transplanting, the whole plant tissues were rapidly frozen with liquid nitrogen to make the plant more fragile. The frozen plant tissues were ground before shaking in the buffer (Fido et al. 2004). Each dried sample was mixed with $1 \mathrm{ml}$ of water-soluble protein extraction buffer in Eppendorf tube and left in refrigerator overnight, then vortexed for $15 \mathrm{~s}$ and centrifuged at $5000 \mathrm{rpm}$ on $4{ }^{\circ} \mathrm{C}$ for $15 \mathrm{~min}$. The supernatants containing water-soluble proteins were transferred to new Eppendorf tubes and kept at deep-freezer until electrophoretic analysis.

\section{Molecular weight estimation by electrophoresis}

To determine the relative molecular weight of extracted proteins, sodium dodecyl sulphate polyacrylamide gel electrophoresis (SDS-PAGE) was performed on a stacking and separating gel according to the method of Laemmli (1970) using Mini-gel electrophoresis (BioRad, USA). The molecular weight of the isolated proteins was estimated in comparison to standard molecular weight markers (standard protein markers, 11-245 kDa; Sigma, USA). The protein bands were visualized by staining with Coomassie Brilliant Blue G-250 (Sigma, USA) after documentation (Darwesh et al. 2015).

\section{Statistical analysis}

Tukey test for multiple comparisons among means was utilized (Neler et al. 1985).

\section{Results}

Laboratory tests

Results in Table 1 indicate that all tested treatment concentrations significantly reduced the linear growth of both fungi. Complete inhibition of linear growth was obtained with 4 and $6 \mathrm{~g} / \mathrm{l}$ for $R$. solani and F. solani, respectively. Concentration at $2 \mathrm{~g} / \mathrm{l}$ showed moderate effect.

\section{Field experiment}

Results in Table 2 reveal that all tested concentrations significantly reduced the disease incidence and severity. The highest reduction of disease incidence and severity was obtained with potassium silicate and calcium silicate applied as soil treatment + foliar sprays which reduced the disease incidence and severity by 92.7 and 91.9, and 91.7 and $91.1 \%$, respectively, followed by sodium silicate applied as soil treatment + foliar spray which reduced the disease incidence and severity by 81.2 and $82.4 \%$. Other treatments showed moderate effect.

Table 1 Effect of silicon as well as potassium, sodium, and calcium silicates on linear growth of strawberry black root rot fungi under laboratory conditions

\begin{tabular}{|c|c|c|c|c|c|}
\hline \multirow[t]{2}{*}{ Treatment } & \multirow[t]{2}{*}{ Concentration (g/l) } & \multicolumn{2}{|l|}{ Fusarium solani } & \multicolumn{2}{|c|}{ Rhizoctonia solani } \\
\hline & & Linear growth & Reduction \% & Linear growth & Reduction \% \\
\hline \multirow[t]{3}{*}{ Silicon } & 2.0 & $44.5 b^{*}$ & 50.6 & 38.0 & 57.8 \\
\hline & 4.0 & $21.0 \mathrm{~d}$ & 76.7 & $00.0 \mathrm{~d}$ & 100.0 \\
\hline & 6.0 & $00.0 \mathrm{e}$ & 100.0 & $00.0 \mathrm{~d}$ & 100.0 \\
\hline \multirow[t]{3}{*}{ Potassium silicate } & 2.0 & $48.0 \mathrm{~b}$ & 46.7 & $40.2 \mathrm{~b}$ & 55.6 \\
\hline & 4.0 & $25.0 \mathrm{C}$ & 72.2 & $00.0 \mathrm{~d}$ & 100.0 \\
\hline & 6.0 & $00.0 \mathrm{e}$ & 100.0 & $00.0 \mathrm{~d}$ & 100.0 \\
\hline \multirow[t]{3}{*}{ Sodium silicate } & 2.0 & $50.0 \mathrm{~b}$ & 44.4 & $35.0 \mathrm{c}$ & 61.1 \\
\hline & 4.0 & $18.0 \mathrm{~d}$ & 80.0 & $00.0 \mathrm{~d}$ & 100.0 \\
\hline & 6.0 & $00.0 \mathrm{e}$ & 100.0 & $00.0 \mathrm{~d}$ & 100.0 \\
\hline \multirow[t]{3}{*}{ Calcium silicate } & 2.0 & $33.0 \mathrm{c}$ & 63.3 & $44.0 \mathrm{~b}$ & 51.1 \\
\hline & 4.0 & $18.0 \mathrm{~d}$ & 80.0 & $00.0 \mathrm{~d}$ & 100.0 \\
\hline & 6.0 & 00.0 e & 100.0 & $00.0 \mathrm{~d}$ & 100.0 \\
\hline Actamyl (Fungicide) & 3.0 & $00.0 \mathrm{e}$ & 100.0 & $00.0 \mathrm{~d}$ & 100.0 \\
\hline Control & 0.0 & $90.0 \mathrm{a}$ & 0.0 & $90.0 \mathrm{a}$ & 0.0 \\
\hline
\end{tabular}

*Figures with the same letter in a column are not significantly $(P \leq 0.05)$ different 
Table 2 Effect of silicon as well as potassium, sodium and calcium silicates on root rot disease incidence and severity of strawberry plants under field conditions

\begin{tabular}{|c|c|c|c|c|c|}
\hline \multirow[t]{2}{*}{ Treatment } & \multirow[t]{2}{*}{ Application } & \multicolumn{4}{|c|}{ Black root rot disease } \\
\hline & & Disease incidence & Reduction\% & Disease severity & Reduction $\%$ \\
\hline \multirow[t]{2}{*}{ Silicon } & Soil & $12.7 b^{*}$ & 69.0 & $10.2 \mathrm{~b}$ & 72.4 \\
\hline & Soil + foliar & $6.7 d$ & 83.7 & $6.0 \mathrm{c}$ & 83.8 \\
\hline \multirow[t]{2}{*}{ Potassium silicate } & Soil & $9.3 \mathrm{c}$ & 77.3 & $8.5 \mathrm{bc}$ & 77.0 \\
\hline & Soil + foliar & $3.0 \mathrm{f}$ & 92.7 & $3.0 \mathrm{e}$ & 91.9 \\
\hline \multirow[t]{2}{*}{ Sodium silicate } & Soil & $12.3 \mathrm{~b}$ & 70.0 & $10.2 \mathrm{~b}$ & 72.4 \\
\hline & Soil + foliar & $7.7 \mathrm{~d}$ & 81.2 & $6.5 \mathrm{c}$ & 82.4 \\
\hline \multirow[t]{2}{*}{ Calcium silicate } & Soil & $9.7 \mathrm{c}$ & 76.3 & $8.5 b c$ & 77.0 \\
\hline & Soil + foliar & $3.4 \mathrm{f}$ & 91.7 & $3.3 \mathrm{e}$ & 91.1 \\
\hline \multirow[t]{2}{*}{ Actamyl $3 \mathrm{~g} / \mathrm{L}$ (Fungicide) } & Soil & 5.3 e & 87.1 & $5.7 \mathrm{~d}$ & 84.6 \\
\hline & Soil + foliar & 4.7 e & 88.5 & $5.2 \mathrm{~d}$ & 85.9 \\
\hline Control & & $41.0 \mathrm{a}$ & 0.0 & $37.0 \mathrm{a}$ & 0.0 \\
\hline
\end{tabular}

* Figures with the same letter in a column are not significantly $(P \leq 0.05)$ different

Effect on weight of strawberry plants under field conditions Results in Table 3 reveal a significant increase in the fresh and dry weight of strawberry plants by all tested concentrations. The highest increase was obtained with potassium silicate and calcium silicate applied as soil treatment + foliar spray which increased the fresh and dry weight of strawberry plants by 82.2 and 166.7 , and 81.8 and $158.3 \%$, respectively. Other treatments showed intermediate effect.

\section{Effect on strawberry yield}

All tested concentrations significantly increased strawberry fruit yield (Table 4). The highest increase was obtained with potassium silicate and calcium silicate applied as soil treatment + foliar sprays which increased fruit yield by 77.1 and $72.8 \%$, respectively. Potassium silicate and calcium silicate applied as soil treatment as well as sodium silicate and silicon as soil + foliar spray increased fruit yield more than $35.7 \%$ with no significant difference compared to the fungicide (Actamyl).

\section{Effect on protein patterns}

Results in Table 5 and Fig. 1 indicate that 12, 10, 9, and 8 new protein bands appeared in the treatments of calcium silicate, sodium silicate, potassium silicate, and silicon, respectively.

\section{Discussion}

Black root rot is a disease complex of strawberry caused by Rhizoctonia fragariae, Ceratobasidium [teleomorph] sp., Coniothyrium fuckelii, Diapleella coniothyrium [teleomorph] $=$ Leptosphaeria coniothyrium, Hainesia lythri, Discohainesia oenotherae [teleomorph], Idriella lunata, Pyrenochaeta sp., Pythium spp., Pythium ultimum (Anonymous 2018). It is a serious, yield-limiting

Table 3 Effect of silicon as well as potassium, sodium and calcium silicates on weight of strawberry plants under field conditions

\begin{tabular}{|c|c|c|c|c|c|}
\hline \multirow[t]{2}{*}{ Treatment } & \multirow[t]{2}{*}{ Application } & \multicolumn{4}{|c|}{ Weight (g)/plant } \\
\hline & & Fresh & Increase \% & Dry & Increase \% \\
\hline \multirow[t]{2}{*}{ Silicon } & Soil & $160.0 C^{*}$ & 45.5 & $17.0 \mathrm{~d}$ & 41.7 \\
\hline & Soil+ foliar & 180.1 b & 63.7 & $22.0 \mathrm{~b}$ & 83.3 \\
\hline \multirow[t]{2}{*}{ Potassium silicate } & Soil & $182.0 \mathrm{~b}$ & 65.5 & $22.1 \mathrm{~b}$ & 84.2 \\
\hline & Soil+ foliar & $200.4 \mathrm{a}$ & 82.2 & $32.0 \mathrm{a}$ & 166.7 \\
\hline \multirow[t]{2}{*}{ Sodium silicate } & Soil & $157.0 \mathrm{C}$ & 42.7 & $19.2 \mathrm{C}$ & 60.0 \\
\hline & Soil+ foliar & $180.0 \mathrm{~b}$ & 63.6 & $22.0 \mathrm{~b}$ & 83.3 \\
\hline \multirow[t]{2}{*}{ Calcium silicate } & Soil & $177.0 \mathrm{~b}$ & 60.9 & $19.5 \mathrm{C}$ & 62.5 \\
\hline & Soil+ foliar & $200.0 \mathrm{a}$ & 81.8 & 31.0 a & 158.3 \\
\hline \multirow[t]{2}{*}{ Actamyl $3 \mathrm{~g} / \mathrm{L}$ (Fungicide) } & Soil & $150.0 \mathrm{c}$ & 36.4 & $18.2 \mathrm{~d}$ & 51.7 \\
\hline & Soil+ foliar & $150.0 \mathrm{C}$ & 36.4 & $18.2 \mathrm{~d}$ & 51.7 \\
\hline Control & & $110.0 \mathrm{~d}$ & 0.0 & $12.0 \mathrm{e}$ & 0.0 \\
\hline
\end{tabular}

*Figures with the same letter in a column are not significantly $(P \leq 0.05)$ different 
Table 4 Effect of silicon as well as potassium, sodium, and calcium silicates on strawberry fruit yield under field conditions

\begin{tabular}{llll}
\hline Treatment & Application & Yield (tons/feddan) & Increase \% \\
\hline Silicon & Soil & $8.2 \mathrm{~d}^{*}$ & 17.1 \\
& Soilt foliar & $9.8 \mathrm{~b}$ & 40.0 \\
Potassium silicate & Soil & $10.0 \mathrm{~b}$ & 42.9 \\
& Soil+ foliar & $12.4 \mathrm{a}$ & 77.1 \\
Sodium silicate & Soil & $8.0 \mathrm{~d}$ & 14.3 \\
& Soil+ foliar & $9.5 \mathrm{cb}$ & 35.7 \\
Calcium silicate & Soil & $10.2 \mathrm{~b}$ & 45.7 \\
& Soil+ foliar & $12.1 \mathrm{a}$ & 72.8 \\
Actamyl 3 g/L & Soil & $10.0 \mathrm{~b}$ & 42.9 \\
(Fungicide) & Soil+ foliar & $10.0 \mathrm{~b}$ & 42.9 \\
Control & & $7.0 \mathrm{~d}$ & 0.0 \\
\hline
\end{tabular}

*Figures with the same letter are not significantly $(P \leq 0.05)$ different

disease that reduces annual production by about $30 \%$ in the Western Cape Province of South Africa, recognized as the most important root disease of strawberries in this area (Botha et al. 2001; Juber et al. 2014; Fang et al. 2013). In Egypt, the disease is frequently caused by $F$. solani and $R$. solani but exact yield loss is unknown. We tested herein four concentrations, i.e., $0,2,4$, and $6 \mathrm{~g} / \mathrm{l}$ of silicon,

Table 5 Molecular weights for protein patterns of strawberry plants as affected with silicon and silicate salts analyzed using gelaxiralyzer 2010 program

\begin{tabular}{lllll}
\hline Control & Potassium silicate & Calcium silicate & Sodium silicate & Silicon \\
\hline 159 & 191 & 173 & 174 & 182 \\
119 & 170 & 156 & 156 & 165 \\
105 & 151 & 136 & 136 & 145 \\
87 & 132 & 130 & 127 & 121 \\
70 & 116 & 117 & 113 & 106 \\
60 & 106 & 111 & 99 & 100 \\
55 & 98 & 98 & 94 & 88 \\
48 & 80 & 93 & 83 & 79 \\
44 & 65 & 81 & 67 & 71 \\
39 & 54 & 75 & 63 & 67 \\
35 & 50 & 67 & 52 & 63 \\
33 & 45 & 64 & 48 & 58 \\
32 & 42 & 58 & 45 & 50 \\
30 & 38 & 49 & 41 & 43 \\
& 35 & 46 & 38 & 39 \\
& 32 & 41 & 36 & 37 \\
& & 37 & 34 & 35 \\
& & 36 & 33 & 33 \\
& & 34 & 30 & 32 \\
\hline
\end{tabular}

potassium, sodium, and calcium silicates, to study their effect on linear growth of strawberry black root fungi ( $F$. solani and $R$. solani) under laboratory conditions. Results indicated that all tested concentrations significantly reduced the linear growth of both fungi. Complete inhibition of linear growth was obtained with 4 and $6 \mathrm{~g} / \mathrm{l}$ for $R$. solani and $F$. solani, respectively. All concentrations tested herein significantly reduced the disease incidence and severity under field conditions with their differences. Consequently, the highest yield increase was obtained with potassium and calcium silicates applied as soil treatment + foliar spray.

As numerous pathogens could be entangled in the black root-rot complex, no single control measure is totally effective. Therefore, cultural practices should be strictly followed as preventive measures before applying the aforementioned treatments as a last resort. Many Egyptian growers have already put some of these practices in effect especially avoiding heavy, wet soils and improve drainage in marginal soils by tactful irrigation system and tillage as well as planting on raised beds. Moreover, the source of seedlings must be examined to ensure healthy whiterooted plants. Also, it is essential to incorporate organic matter such as buffalo/poultry fertilizer as well as straw from a rotational grain crop before bed construction. On the other hand, some Egyptian growers neglect crop rotation although strawberry should be rotated for at least 2 years before replanting. Preplant fumigation of the soil is frequently helpful, but some unauthorized fumigants, sometimes used by Egyptian growers, such as methyl bromide should be avoided.

Bekker et al. (2006) reported the effect of soluble potassium silicate $\left(20.7 \% \mathrm{SiO}_{2}\right)$ on Phytophthora cinnamomi, Sclerotinia sclerotiorum, Pythium sp., Mucor pusillus, Drechslera sp., Fusarium oxysporum, F. solani, Alternaria solani, Colletotrichum coccodes, Verticillium theobromae, Curvularia lunata, and Stemphylium herbarum. Inhibition of mycelial growth was dose-related with $100 \%$ inhibition at $80 \mathrm{ml}(\mathrm{pH} 11.7)$ and $40 \mathrm{ml}(\mathrm{pH} 11.5)$ soluble potassium silicate per liter of agar, for all fungi tested with the exception of Drechslera sp. and F. oxysporum at $40 \mathrm{ml}$ in one experiment. Only Sclerotinia sclerotiorum and Phytophthora cinnamomi were completely inhibited at all soluble potassium silicate concentrations between 5 and $80 \mathrm{ml} / 1$ agar, while all the other fungi were only partially inhibited at potassium silicate concentrations of 5,10 , and $20 \mathrm{ml} / 1$ agar. Likewise, percentage inhibition was positively correlated with dosage. Bekker et al. (2009) demonstrated in vitro inhibition of mycelial growth of phytopathogenic fungi grown on potassium silicate-amended media.

Nada et al. (2014) stated that potassium silicate was more effective than calcium and sodium silicates in reducing damping-off incidence and in improving plant growth parameters of coriander. Also, Kanto et al. (2006) 

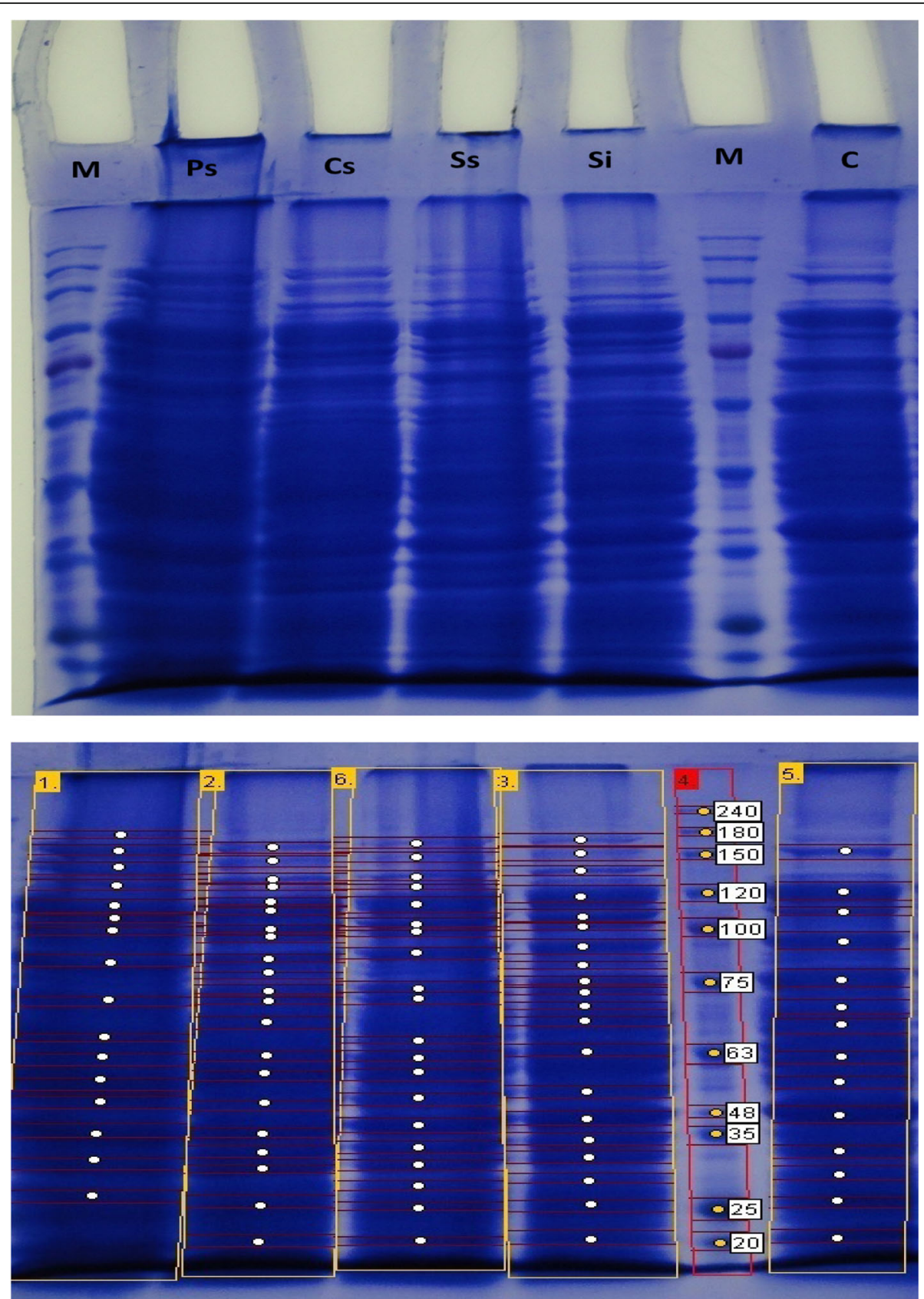

Fig. 1 Protein patterns of strawberry plants as affected with silicon and silicate salts. Upper patterns: Ps = potassium silicate, Cs = calcium silicate, Ss = sodium silicate, $\mathrm{Si}=$ silicon, $\mathrm{C}=$ Control, $\mathrm{M}=$ marker; Lower patterns: 1 = potassium silicate, 2 = calcium silicate, $3=$ sodium silicate, $4=$ marker, $5=$ Control, $6=$ silicon

reported that both potassium and calcium silicates suppressed Fusarium wilt of cucumber for 3 years more than sodium silicate. They also found that liquid potassium silicate as soil drench to control the powdery mildew of strawberry in the soil acted more efficiently as preventive rather than curative treatment; strawberry leaf treated by silicate was harder than control leaf. Moreover, Jayawardana et al. (2014) reported that root and foliar application of soluble potassium silicate caused decrease in disease incidence and increase in plant growth and fruit quality parameters. Liang et al. (2005) noticed that silicon can prevent pathogen penetration into host tissues. Eventually, it is likely that reduction in disease incidence in plants treated with silicon sources under field conditions is not probably due to the fungistatic effects of silicon, but silicon could act as physical barrier against pathogen penetration or silicon can be used as inducer for defense response in plant (Shen et al. 2010). 
On the other hand, Cherif and Bélanger (1992) found that treating cucumber roots with soluble silicon resulted in an increase in the activities of peroxidase and polyphenoloxidase and that silicon can stimulate accumulation of polymerized phenolic compounds. These results agreed with ours reported herein but for different host and plant pathogen. There are numerous explanations of the silicon role to suppress the rot disease. The emerging role of silicon as a biologically active element capable of improving the natural defense system of the plant; Si-treated plants exhibited increased activity of peroxidases, chitinases, polyphenol oxidases, and flavonoid phytoalexins, which play an important role in the resistance of the plant to fungal pathogens (Fawe et al. 1998). Furthermore, the higher production of glycosylated phenolics, antimicrobial products such as diterpenoid phytoalexins and a proline-rich protein in the silicon-treated plants, indicated that these products can have a role in the protection effects of $\mathrm{Si}$ against plant diseases (Rodrigues et al. 2003, 2010). The bioactivity of Si as a regulator of plant defense mechanisms may be explained through the biochemical properties, e.g., Si binds with hydroxyl groups of proteins which are involved in signal transduction. Also, Si may interfere with cationic co-factors of the enzymes which influence pathogenesisrelated (PR) events.

Nevertheless, plant reactions to the attacking plant pathogens are very complex and involve the activation of set of genes, encoding different proteins. These proteins can induce biochemical and physiological changes in plants, such as physical strengthening of the cell wall through lignification, suberization, and callose deposition, by producing phenolic compounds, phytoalexins and PR proteins which subsequently prevent various pathogen invasions (Li et al. 2001; Ebrahim et al. 2011).

Results in the present study indicated that $12,10,9$, and 8 new protein patterns (bands) appeared in the treatments of calcium silicate, sodium silicate, potassium silicate, and silicon, respectively. In this respect, Ryals et al. (1996) reported that production and accumulation of PR proteins in plants in response to invading pathogen and/or stress conditions is very important. Phytoalexins are mainly produced by healthy cells adjacent to localized damaged and necrotic cells, but PR proteins accumulate locally in the infected and surrounding tissues and also in remote uninfected tissues. Production of PR proteins in the uninfected parts of plants can prevent the affected plants from further infection.

\section{Conclusions}

The black root rot becomes a major problem in many strawberry fields in Egypt. To avoid environmental pollution and health hazards in managing the disease, an integrated approach is necessary which includes tactful cultural practices and applying foliar and soil inputs, e.g., silicon salts reported herein. Such an approach can effectively control the disease and enhance strawberry yield.

\section{Abbreviations \\ PR: Pathogenesis-related; Si: Silicon; SDS-PAGE: Sodium dodecyl sulphate polyacrylamide gel electrophoresis}

\section{Acknowledgements}

This study was supported in part by the US-Egypt Project cycle 17 (no. 172) entitled "Preparing and evaluating IPM tactics for increasing strawberry and citrus production."

\section{Authors' contributions}

All authors participated in the development and implementation of the research plan and subsequently written it. All authors read and approved the final manuscript

\section{Funding}

Financial support made by US-Egypt Project fund for Project cycle 17 (no. 172) and National Research Centre, Egypt, is gratefully acknowledged.

\section{Availability of data and materials}

The datasets used and/or analyzed during the current study are available from the corresponding author on reasonable request.

Ethics approval and consent to participate

Not applicable.

\section{Consent for publication}

Not applicable.

\section{Competing interests}

The authors declare that they have no competing interests.

Received: 28 November 2018 Accepted: 27 May 2019

Published online: 07 June 2019

\section{References}

Anonymous 2018 List of strawberry diseases. https:/en.wikipedia.org/wiki/List of_strawberry_diseases. Accessed 27 Nov 2018

Bekker TF, Kaiser C, Labuschagne N (2009) The antifungal activity of potassium silicate and the role of $\mathrm{pH}$ against selected plant pathogenic fungi in vitro. South Afr J PI Soil 26(1). https://doi.org/10.1080/02571862.2009.10639934

Bekker TF, Kaiser C, Merwe R, Labuschagne N (2006) In-vitro inhibition of mycelial growth of several phytopathogenic fungi by soluble potassium silicate. South Afr J PI Soil 23:224-232

Bélanger RR, Bowen PA, Ehret DL, Menzies JG (1995) Soluble silicon: its role in crop and disease management of greenhouse crops. PI Dis 79:329-336

Blokhina O, Virolainen E, Fagerstedt KV (2003) Antioxidants, oxidative damage and oxygen deprivation stress: a review. Ann Botany 91:179-194

Botha A, Denman S, Crous PW, Lamprecht SC (2001) Strawberry diseases: methyl bromides out 'black root rot in. Deciduous Fru Grow 51:25-27

Ceja-Torres LF, Mora-Aguilera G, Mora-Aguilera A (2014) Agronomical management influence on the spatiotemporal progress of strawberry dry wilt in Michoacán, Mexico. Afr J Agric Res 9(4):513-520

Cherif M, Belanger RR (1992) Use of potassium silicate amendments in recirculating nutrient solutions to suppress Pythium ultimum on long English cucumber. PI Dis 79:1008-1011

Darwesh OM, Moawad H, Barakat OS, Abd El-Rahim WM (2015) Bioremediation of textile reactive blue azo dye residues using nanobiotechnology approaches. Res J Pharmaceut Biol Chem Sci 6(1):1202-1211

Datnoff LE, Synder GH, Korndorfer GH (2001) Silicon in agriculture. Elsevier Science, New York

Ebrahim S, Usha K, Singh B (2011) Pathogenesis related (PR) proteins in plant defense mechanism. Res Tech Adv 6:1043-1054

El-Shemy AA, Khafagy YS, Al-Genteery AMM (2013) Cultivation and production of strawberry. General Directorate of Agricultural Culture, Egypt Minist Agric (in Arabic), Cairo: Tech issue no. 9/2013

Fang XD, Finnegan MP, Barbetti MJ (2013) Wide variation in virulence and genetic diversity of binucleate Rhizoctonia isolates associated with root rot of strawberry in western Australia. PLoS One 8(2):e55877 
Fawe A, Abou-Zaid M, Menzies JG, Bélanger RR (1998) Silicon mediated accumulation of flavonoid phytoalexins in cucumber. Phytopath 88:396-401

Fido RJ, Mills ENC, Rigby NM, Shewry PR (2004) Protein extraction from plant tissues. Methods Mol Biol 244:21-27

Forbes JC, Watson RD (1992) Plants in agriculture. Cambridge University Press, UK Hutton DG, Gomez AO, Mattner SW (2013) Macrophomina phaseolina and its association with strawberry crown rot in Australia. Int J Fru Sci 13(1-2):149-155

Jayawardana HARK, Weerahewa HLD, Saparamadu MDJS (2014) Effect of root or foliar application of soluble silicon on plant growth, fruit quality and anthracnose development of capsicum. Trop Agric Res 26(1):74-81

Juber KS, Al-Juboory HH, Al-Juboory SB (2014) Fusarium wilt disease of strawberry caused by Fusarium oxysporum f. sp. Fragariae in Iraq and its control. J Exper Biol Agric Sci 2(4):419-427

Kanto T, Miyoshi A, Ogawa T, Maekawa K, Aino M (2006) Suppressive effect of liquid potassium silicate on powdery mildew of strawberry in soil. J Gener PI Path 72(3):137-142

Khalifa MMA, Noher A, Mahmoud M, Abou-Zeid NM (2013) Performance of some biofungicides on the most onion economic diseases compared to recommended fungicide in Egypt. I-White rot disease control and economical feasibility. Egypt J Appl Sci 28(1):40-65

Kumar PT (2007) Biological management of alternaria blight of onion. M. Sc. Thesis, College of Agriculture, Dharwad University of Agricultural sciences, Dharwad, $\mathrm{p} 112$

Laemmli UK (1970) Cleavage of structural proteins during the assembly of the head of bacteriophage T4. Nature 227:680-685

Li WL, Faris JD, Muthukrishnan S, Liu DJ, Chen PD, Gill BS (2001) Isolation and characterization of novel cDNA clones of acidic chitinases and $\beta-1,3-g$ lucanases from wheat spikes infected by Fusarium graminearum. Theor Appl Genet 102:353-362

Liang YC, Sun WC, Si J, Romheld V (2005) Effects of foliar- and root-applied silicon on the enhancement of induced resistance to powdery mildew in Cucumis sativus. PI Path 54:678-685

Ma JF (2004) Role of silicon in enhancing the resistance of plants to biotic and abiotic stresses. Soil Sci PI Nutr 50:11-18

Morocko I (2006) Characterization of the strawberry pathogen Gnomonia fragariae, and biocontrol possibilities. Doctoral thesis. Swedish University of Agricultural Sciences, Uppsala

Nada MGA, Doaa A, Imarah A, Halawa AEA (2014) Efficiency of some silicon sources for controlling damping-off of coriander (Coriandrum sativum L.) in Egypt. Egypt J Phytopathol 42(2):73-90

Neler J, Wassermann W, Kutner MH (1985) Applied linear statistical models. Regression, analysis of variance and experimental design, 2nd edn. Irwin Inc, Homewood Illionois

Rodrigues FA, Benhamou N, Datnoff JB, Jones B, Bélanger RR (2003) Ultrastructural and cytochemical aspects of silicon-mediated rice blast resistance. Phytopath 93:535-546

Rodriques FA, Duarte HSS, Rezende DC, Wordell JA, Filho GH, Korndörfer K, Zambolim KL (2010) Foliar spray of potassium silicate on the control of angular leaf spot on beans. J PI Nutr 33(4):2082-2093

Ryals JA, Neuenschwander UH, Willits MG, Molina A, Steiner HY, Hunt MD (1996) Systemic acquired resistance. PI Cell 8:1809-1819

Shen GH, Xue QH, Tang M, Chen Q, Wang LN, Duan CM, Xue L, Zhoo J (2010) Inhibitory effects of potassium silicate of five soil-borne phytopathogenic fungi in vitro. J PI Dis Prot 117(4):180-184

Wang M, Gao L, Dong S, Sun Y, Shen Q, Guo S (2017) Role of silicon on plantpathogen interactions. Front PI Sci 8:701. https://doi.org/10.3389/fpls.2017. 00701

\section{Publisher's note}

Springer Nature remains neutral with regard to jurisdictional claims in published maps and institutional affiliations.

\section{Submit your manuscript to a SpringerOpen ${ }^{\circ}$ journal and benefit from:}

- Convenient online submission

- Rigorous peer review

- Open access: articles freely available online

- High visibility within the field

- Retaining the copyright to your article

Submit your next manuscript at $\boldsymbol{\nabla}$ springeropen.com 